\title{
Narrative and Metaphor in Education
}

Look Both Ways

\section{Edited by Michael Hanne and Anna A. Kaal}


First published 2019

by Routledge

2 Park Square, Milton Park, Abingdon, Oxon OXI4 4RN

and by Routledge

52 Vanderbilt Avenue, New York, NY 10017

Routledge is an imprint of the Taylor \& Francis Group, an informa business

(C) 2019 selection and editorial matter, Michael Hanne and

Anna A. Kaal; individual chapters, the contributors.

The right of the editor to be identified as the author of the editorial material, and of the authors for their individual chapters, has been asserted in accordance with sections 77 and 78 of the Copyright, Designs and Patents Act 1988.

All rights reserved. No part of this book may be reprinted or reproduced or utilised in any form or by any electronic, mechanical, or other means, now known or hereafter invented, including photocopying and recording, or in any information storage or retrieval system, without permission in writing from the publishers.

Trademork notice: Product or corporate names may be trademarks or registered trademarks, and are used only for identification and explanation without intent to infringe.

British Library Cataloguing-in-Publication Data

A catalogue record for this book is available from the British Library

Library of Congress Cataloging-in-Publication Data

Names: Hanne, Michael, editor.| Kaal, Anna A., editor.

Title: Narrative and metaphor in education : look both ways /

Edited by Michael Hanne and Anna A. Kaal.

Description: Abingdon, Oxon ; New York, NY : Routledge, 2019.1

Includes bibliographical references.

Identifiers: LCCN 2018036222 (print) | LCCN 2018048066

(ebook) | ISBN 978042945919 | (E-book) | ISBN

978||38310872 (hbk) | ISBN 9780429459 I9। (ebk)

Subjects: LCSH: Storytelling in education. | Narrative inquiry

(Research method) | Metaphor-Social aspects.

Classification: LCC LBI042 (ebook) | LCC LBI042 .N335 2019 (print) | DDC 372.67/7--dc23

LC record available at https://lccn.loc.gov/2018036222

ISBN: 978- | - | 38-31087-2 (hbk)

ISBN: 978-0-429-459!9-I (ebk)

Typeset in Bembo

by Apex CoVantage, LLC 


\section{Contents}

\section{PART I}

Introduction

1 Looking at both narrative and metaphor in education MICHAEL HANNE AND ANNA A. KAAL

\section{PART 2}

Narrative, metaphor, and learning

2 Honouring the role of narrative and metaphor in education

3 You in motion: stories and metaphors of becoming in narrative learning environments

DAVID BABOULENE, ALEX GOLDING, SJOERD-JEROEN MOENANDAR, AND FLOOR VAN RENSSEN

4 An ecology for learning and teaching: niches for theories within the habitat of learning

\section{PART 3}

Narrative and metaphor in teaching a range of disciplines

5 Multiperspectivity in the history classroom: the role of narrative and metaphor 
6 Resonant Work: metaphor and narrative in music, learning, and life

MARGARET S. BARRETT AND SANDRA L. STAUFFER

7 How metaphor and narrative interact in stories of forces of nature

HANS U. FUCHS, ANNAMARIA CONTINI, ELISABETH DUMONT, ALESSANDRA LANDINI, AND FEDERICO CORNI

PART 4

Narrative, metaphor, and the politics of education

8 Narrative and metaphor in special educational needs: shaping thought, discourse, and practice JANINE TALLEY

9 Uneducation: narrative and metaphor in subjugated knowledge

SANDY FARQUHAR AND PETER FITZSIMONS

10 Education reform in Croatia: a tug of war IVANA MARINIĆ AND KSENIJA BENČINA

\section{PART 5}

Narrative and metaphor in intercultural education

11 Stories about language: raising learners' language awareness using metaphor

ANNA A. KAAL AND SEBASTIAAN DÖNSZELMANN

12 Journeys of learning: dimensions of metaphor and narrative landscapes across cultures

MARTIN CORTAZZI AND LIXIAN JIN

13 Teaching for reconciliation: insights from an augmented reality project 


\section{PART 6}

Narrative and metaphor in the education of teachers and counsellors

14 Teaching as performance: using narrative and metaphor in initial teacher education

DOROTHY MORRISSEY

15 Four seasons of composing stories to live by: teaching, learning, and research strategies in teacher education JANET DYSON AND CLARE SMITH

16 Narrative and metaphor as two sides of the same coin: the case for using both in research and teacher development

VOLHA ARKHIPENKA AND SVETLANA LUPASCO

17 Narrative and metaphor in constructing teacher identity, self-positioning, and coherence YANPING FANG AND KEN MIZUSAWA

18 Weaving threads into a basket: facilitating counsellor identity creation through metaphor and narrative

SARAH PENWARDEN

\section{PART 7}

Narrative inquiry needs metaphor, too

19 A journey through narrative inquiry to autoethnography GWYNETH JAMES

20 Lingering departures: reverberations through, and in, narrative inquiry response communities 